\title{
Phosphorus and Metals Leaching from Green Roof Substrates and Aggregates Used in Their Composition
}

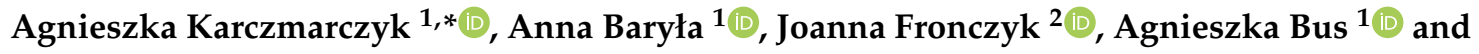 \\ Józef Mosiej $^{3}$ \\ 1 Department of Environmental Development, Institute of Environmental Engineering, Warsaw University of \\ Life Sciences-SGGW, Nowoursynowska 159, 02-776 Warsaw, Poland; anna_baryla@sggw.pl (A.B.); \\ agnieszka_bus@sggw.pl (A.B.) \\ 2 Department of Revitalization and Architecture, Institute of Civil Engineering, Warsaw University of Life \\ Sciences-SGGW, Nowoursynowska 159, 02-776 Warsaw, Poland; joanna_fronczyk@sggw.pl \\ 3 Department of Landscape Architecture, Institute of Environmental Engineering, Warsaw University of Life \\ Sciences-SGGW, Nowoursynowska 159, 02-776 Warsaw, Poland; jozef_mosiej@sggw.pl \\ * Correspondence: agnieszka_karczmarczyk@sggw.pl
}

Received: 18 December 2019; Accepted: 24 January 2020; Published: 28 January 2020

\begin{abstract}
Green roofs are constructions made of different layers, each serving a dedicated function. Substrates and materials used in their composition are essential from the point of view of rainwater retention and plant development, but they may have an adverse effect on runoff quality. Literature studies show that phosphorus and heavy metals are of main importance. The total roofs area covered with green increased in the last years in cities as they are efficient in retention of rainwater and delaying of the runoff, therefore, protecting the cities against floods. As green roofs filtrate a significant amount of rainwater, materials used in substrates composition should be carefully selected to protect urban receivers against pollution. The aim of this study was to assess phosphorus and heavy metals leaching from different green roof substrates and their components with the focus on green roof runoff quality. Both commercially made green roof substrates and often used compounds (construction aggregates) were tested in laboratory batch tests for $\mathrm{P}, \mathrm{Cu}, \mathrm{Ni}, \mathrm{Cd}$, and $\mathrm{Zn}$ content in extracts. Based on the results of this study, it could be emphasized that a large part of commonly used construction aggregates can be a source of phosphorus, some also can release elevated values of nickel. Therefore, the materials should be carefully tested before use in the green roof substrate composition, not only for their physical properties reflecting water retention capacity, but also for chemical composition.
\end{abstract}

Keywords: green roofs; phosphorus; heavy metals; rainwater runoff

\section{Introduction}

Green roofs are a popular measure of rainwater management in cities. The total roof surface covered with green increased last year [1], as they proved to be efficient in rainwater retention and delaying of runoff, and therefore protecting the cities against flooding. Other benefits, as reduction of temperature or air quality improvement caused, that green roofs are at the top of the list of measures recommended by strategy for adaptation cities to climate change [2]. This is likely to significantly increase the area of green roofs in the coming years. Between well-known and indisputable benefits of green roofs $[1,3,4]$, there is one aspect that still raises discussion between specialists. It concerns the impact of green roofs on runoff quality [5].

Green roofs are engineered constructions made of different layers, each serving a dedicated function. From the waterproof barrier upwards, the standard green roof system built up consists of: 
Anti-bonding layer, separation layer, root barrier, mechanical protection, drainage layer, filter layer, vegetation supporting layer (growing medium), and vegetation [6]. When the growing medium is not able to meet the water retention demand, the water storage is needed and it can be integrated into the vegetation-supporting layer and/or into the drainage layer and/or be a separate layer [6]. For the purpose of this study, we will use the name "substrate" for growing medium or supporting retention layer, both responsible for rainwater retention and plant development.

Green roof substrates filtrate a significant amount of rainwater and they may have an adverse effect on runoff quality. Literature studies show that phosphorus and heavy metals are of main importance.

Urban waters are already rich in phosphorus [7] and progressive urbanization leads to increased phosphorus concentration [8,9]. According to [10], the load of phosphorus discharged to the receiver from stormwater drainage system amounts to $1.5 \mathrm{~kg} / \mathrm{ha}$ of sealed area. Stormwater systems were responsible for $9.2 \%$ of total phosphorus load discharged to Baltic Sea in 2012 [11]. Green roofs are a source of phosphorus of increasing importance in urban water systems.

The concentration of phosphorus in green roof runoff, is found to be elevated relative to the conventional roofs [12-15] and can exceed $1 \mathrm{mg} / \mathrm{L}$ [15-18]. Evaluation of the performance of a green roof for nutrient retention versus input rainfall made by Gregoire and Clausen [19] also showed that $P$ concentrations exported from the green roof were greater than those observed in precipitation, however, an analysis of mass export suggested that the green roof actually retained nutrients and metals mass by virtue of its volume retention capacity. An opposite situation has been reported in the previous study [20]. Simulation of the rainfall of $470 \mathrm{~mm}$ (reflecting the precipitation from growing season in Poland in 2013), resulted in phosphorus leaching from 0.337 to $2.351 \mathrm{mg} / \mathrm{kg}$ of different substrates and was much higher than the load of phosphorus supplied with precipitation. This study has also shown a high correlation between phosphorus content estimated by $\mathrm{HCl}$ extraction and cumulative load in leachate tests, suggesting that the batch of $\mathrm{HCl}$ extraction test can be recommended for the comparison and selection of substrates with the focus on potential P leaching [20].

A high phosphorus concentration in green roof runoff is often explained by the roof age. The water quality performance of green roofs is expected to be different between their early and mature stages because roofs might act as a source of pollution in the early stage while as a sink of pollution at their mature stage [21]. Buffam and Mitchell [22] summed up, that in general P leaching decreases over time due to gradual leaching of available $\mathrm{P}$ in the green roof substrate and plant establishment. Plants reduce pollution levels by extending water retention time and taking up nutrients from the substrate [5]. A long-term study (ranging from 1 to 3 years post-construction) of runoff water quality from a $46 \mathrm{~m}^{2}$ green roof in Cincinnati [23] revealed that green roof runoff chemistry was distinctly different than precipitation or traditional roof runoff, and also exhibited striking seasonal patterns. The concentration of phosphate in green roof runoff was higher in the summer growing season than any other season [23].

Stormwater runoff is a known source of heavy metals in the environment. The most common heavy metals are $\mathrm{Pb}, \mathrm{Zn}$, and $\mathrm{Cu}$. The others, such as $\mathrm{Hg}, \mathrm{Cd}$, and $\mathrm{Ni}$, are present in lower concentrations [24,25]. Czemiel Berndtsson et al. [26] concluded that concentrations of heavy metals in green roof runoff are generally lower than concentrations of heavy metals in urban runoff from hard surfaces and correspond to moderately polluted natural water [17,26]. Another study [27] compared two different green roofs in New Zealand. They found copper concentrations in one living roof runoff 3-4 times greater than the other roof runoff, while the control roof runoff copper concentrations were lower at both sites, suggesting that the substrate and/or plants were a source of copper in the discharge. They stated that this was a reason of the substrate composition (16 vs. $5 \mathrm{mg} / \mathrm{kg}$ ) combined with a lower C:N in the first roof and lower plant cover, carbon mineralization, and leaching contributing to copper mobility. Chen and $\mathrm{Li}$ [28] found that heavy metals concentration in green roof runoff ranged from 9.5 to $56.4 \mu \mathrm{g} / \mathrm{L}$ for $\mathrm{Cu}$, from 2.1 to $12.9 \mu \mathrm{g} / \mathrm{L}$ for $\mathrm{Zn}$, and from 0.7 to $3.7 \mu \mathrm{g} / \mathrm{L}$ for Ni. Ferrans et al. [15] analyzed the effect of green roofs on runoff water quality and identified a significant increase in the presence of most of the parameters compared to control roofs. Results for metals were highly variable 
depending on the specific metal under consideration. For copper, zinc, and nickel values varied due to the type of substrate, but it could not be said that the type of substrate strongly effects these parameters. In this study, however, the type of substrate was shown to be relevant in determining the presence of phosphorus.

Until now, most of the research on green roof runoff quality was focused on monitoring of the pilot- or full-scale roofs and usually show the set or temporary data (expressed as concentration of pollutants) valid for the monitored construction. Such studies are valuable, especially if they are long enough to show specific trends [29], but their results reflect many factors, e.g., green roof vegetation, composition of the substrate and substrate amendments, depth of substrate, roof age, maintenance and climatic conditions (rainfall characteristic, temperature, and light access), etc. [22]. In this study, we used a simplified approach demonstrating the potential for leaching pollutants from green roof substrates and common substrates components. The justification for using this approach for phosphorus leaching has been initially confirmed in [20] and the continuation of this study (unpublished data from four seasons of observation) where the high correlation was observed between phosphorus extractable with hydrochloric acid and the load discharged from substrates with the effluent caused by simulated precipitation.

The aim of this study was to assess potential phosphorus and heavy metals leaching from different green roof substrates and their mineral components with the focus on green roof runoff quality. Even if the problem of green roof runoff pollution is not novel, the approach which is presented was not used in up until now in studies. There is still widespread belief, that the organic substrate component (often being a recycled waste material), is the main factor responsible for nutrient and metals leaching from green roof substrates $[12,23,27,30]$. This study emphasizes that also mineral compounds can be a significant source of pollutants in green roof runoff and should be carefully selected before use.

\section{Materials and Methods}

Both commercially made green roof substrates (13 samples) and often used compounds ( 29 samples of common construction aggregates) were tested. Twelve of the thirteen substrates were sampled from the market before application, one (SMO5) was sampled from the green roof. Seven substrates were characterized as mineral-organic (SMO), two as mineral (SM), and four were the Sedum mate substrates (Ma). The characteristic of tested substrates is shown in Table 1 and the grain size distribution on the background of limit curves is shown in Figure 1.

Table 1. Characteristic of green roof substrates analyzed in the study.

\begin{tabular}{|c|c|c|c|}
\hline Substrate & Bulk Density * $\left(\mathrm{kg} / \mathrm{m}^{3}\right)$ & Organic Matter Content * $(\%)$ & Age/Type \\
\hline \multicolumn{4}{|c|}{ Mineral-Organic Substrates } \\
\hline SMO1 & 1350 & 9 & Fresh/intensive \\
\hline $\mathrm{SMO} 2$ & 1000 & 11 & Fresh/intensive \\
\hline SMO3 & 1100 & 3 & Fresh/intensive \\
\hline $\mathrm{SMO} 4$ & 1100 & 9 & Fresh/intensive \\
\hline SMO5 & 1100 & 2 & 4-years-old/intensive \\
\hline SMO6 & 1500 & 2 & Fresh/intensive \\
\hline SMO7 & 1500 & 2 & Fresh/intensive \\
\hline \multicolumn{4}{|c|}{ Mineral Substrates } \\
\hline SM1 $* *$ & 1400 & - & Fresh/extensive \\
\hline SM2 & 1300 & - & Fresh/extensive \\
\hline \multicolumn{4}{|c|}{ Sedum Mate Substrates } \\
\hline Ma1 & 1000 & 8 & Fresh/extensive \\
\hline Ma2 & 640 & 0.5 & Fresh/extensive \\
\hline Ma3 & 350 & 3 & Fresh/extensive \\
\hline Ma4 & 1300 & 1 & Fresh/extensive \\
\hline Ma5 & 1100 & 2 & Fresh/extensive \\
\hline
\end{tabular}

* Assessment procedures: Bulk density PN EN 1097-3:2000 [31]; organic matter content: As a loss of ignition;

** developed as a low P emission substrate [32]. 


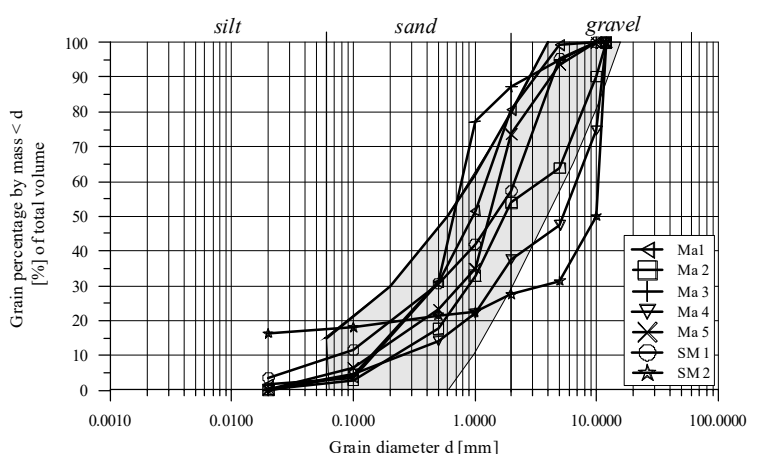

(a)

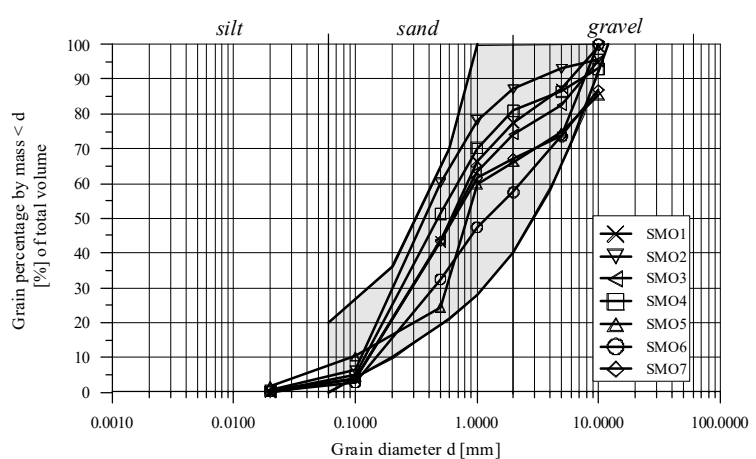

(b)

Figure 1. Grain size distribution of substrates analyzed in the study on the background of limit curves from [33] for extensive (a) and intensive substrates (b). Assessment procedure: PN EN 933-1:2012 [34].

Based on the review given in [32], the most popular mineral components of green roof substrates are stated as clay, sand, volcanic materials, crushed brick, and expanded lightweight materials, while the most popular organic components are compost and peat. For the purpose of this study, tested mineral substrate compounds were characterized as natural origin (17 samples) and man-made (12 samples). Within the compounds of natural origin, 12 samples of sand (S), three samples of gravel $(\mathrm{G})$, and two samples of limestone (L) were tested. In the case of man-made agregates, four samples of crushed red brick (B) and eight samples of lightweight aggregates were selected, of which five were the products made from clay only (LWA) and three from clay with addition of ash (LWA-A) (Figure 2). The characteristics of mineral compounds tested in the study are set in Table 2.

Table 2. Characteristic of green roof substrates compounds analyzed in the study.

\begin{tabular}{|c|c|c|c|c|}
\hline Symbol & Particle Size (mm) & Bulk Density $\left(\mathrm{kg} / \mathrm{m}^{3}\right)^{*}$ & Porosity $(\%) *$ & Description \\
\hline \multicolumn{5}{|c|}{ Materials of Natural Origin } \\
\hline S1 & $0-2$ & 1650 & 40 & Sand \\
\hline $\mathrm{S} 2$ & $0-2$ & 1650 & 40 & Sand \\
\hline S3 & $0-2$ & 1700 & 42 & Sand \\
\hline S4 & $0-2$ & 1600 & 38 & Sand \\
\hline S5 & $0-2$ & 1550 & 37 & Sand \\
\hline S6 & $0-2$ & 1500 & 42 & Sand \\
\hline S7 & $0-2$ & 1600 & 40 & Sand \\
\hline S8 & $0-2$ & 1500 & 39 & Sand \\
\hline S9 & $0-2$ & 1400 & 40 & Sand \\
\hline S10 & $0-2$ & 1400 & 42 & Sand \\
\hline S11 & $0-2$ & 1600 & 38 & Sand \\
\hline $\mathrm{S} 12$ & $0-2$ & 1450 & 40 & Sand \\
\hline G1 & $16-32$ & 1500 & 40 & Gravel \\
\hline G2 & $16-32$ & 1500 & 45 & Gravel \\
\hline G3 & $2-8$ & 1450 & 50 & Gravel \\
\hline L1 & $2-5$ & 1200 & 68 & Limestone \\
\hline L2 & $1-5$ & 1300 & 70 & Limestone \\
\hline \multicolumn{5}{|c|}{ Man-Made Aggregates } \\
\hline LWA1 & $8-16$ & 1100 & 52 & Expanded clay \\
\hline LWA2 & $4-10$ & 320 & 48 & Expanded clay \\
\hline LWA3 & $2-10$ & 300 & 35 & Expanded clay \\
\hline LWA4 & $2-5$ & 400 & 46 & Expanded clay \\
\hline LWA5 & $2-5$ & 400 & 44 & Expanded clay \\
\hline LWA-A1 & $2-5$ & 700 & 55 & Expanded clay and ash \\
\hline LWA-A2 & $10-25$ & 300 & 38 & Expanded clay and ash \\
\hline LWA-A3 & $10-25$ & 670 & 55 & Expanded clay and ash \\
\hline B1 & $5-20$ & 1000 & 60 & Crushed red brick \\
\hline B2 & $5-20$ & 1000 & 60 & Crushed red brick \\
\hline B3 & $5-20$ & 1000 & 60 & Crushed red brick \\
\hline B4 & $2-50$ & 950 & 64 & Crushed red brick \\
\hline
\end{tabular}

* Assessment procedures: Bulk density PN EN 1097-3:2000 [31]; porosity PN-EN 1936:2010 [35]. 


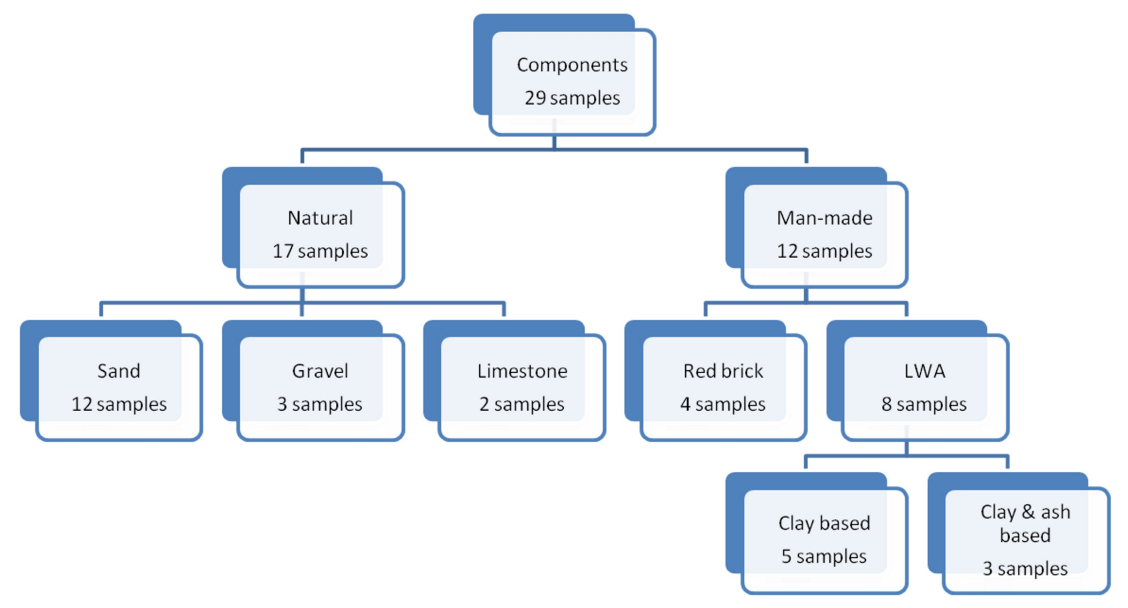

Figure 2. Set of mineral aggregates (green roof substrates components) tested in the study.

All substrates and mineral compounds were tested for $\mathrm{P}, \mathrm{Cu}, \mathrm{Ni}, \mathrm{Cd}$, and $\mathrm{Zn}$ content. Extracts for phosphorus and metals analysis were prepared according to [33,36], respectively. All tests were carried out in triplicate. The concentration of phosphorus was analyzed on a FiaStar analyzer by the ammonium molybdate method in the range of $0.005-1.0$ or $0.1-5.0 \mathrm{mg} \mathrm{PO} 4-\mathrm{P} / \mathrm{L}$. Metals concentration in the eluates were analyzed using atomic absorption spectrometry (iCE-3000, Thermo Scientific, Waltham, MA, USA). Obtained results were recalculated to unit loads in milligram per kilogram and compared with appropriate limit values described in [33,36]. Statistical analysis, covering correlations between analyzed contaminants, as well as contaminants and organic matter content were performed using the Statgraphics Centurion XVI software.

\section{Results and Discussion}

Copper and zinc were found in some extracts of substrates while copper, nickel, and zinc were detected in extracts of mineral substrates components (Figures 3 and 4). In the case of substrates, except Ma5, all detected metals were within the leaching limit values supply for waste acceptable at landfills for inert waste (2003/33/EC) [36]. However, for the mineral materials, nickel limits were exceeded for three sand samples (S8, S11, and S12) and for one crushed red brick sample (B3) (Figure 4). According to [36] this limit is $0.4 \mathrm{mg} / \mathrm{kg}$. Average measured values were $1.79,0.43,1.26$, and $0.48 \mathrm{mg} / \mathrm{kg}$ for S8, S11, S12, and B3, respectively. Recently, the ecotoxicity of nickel is increasingly being considered in the literature [37-39] because of its bioavailability, bio-accumulation, as well as teratogenic and carcinogenic effect on mammals.

Phosphorus was detected in most of the extracts, from both mineral components and ready-made substrates (Figures 3 and 4). As a limit value, $5 \mathrm{mg} / \mathrm{kg}$ was set, following [33]. Only one sample (SM1) of 13 tested substrates was within this limit (Figure 5). SM1 is the mineral substrate developed as a "low P emission substrate" [32]. Mineral-organic substrates (SMO 1-7) were characterized by high P content $(37.68-713.23 \mathrm{mg} / \mathrm{kg})$, as well as second mineral substrate SM2 $(554.16 \mathrm{mg} / \mathrm{kg})$ and Sedum mates Ma1-4 (24.79-917.09 mg/kg). In the case of Sedum mates, high P content can be a result of fertilization, as the plants are cultivated on them before the application on the roof, which was the case with Ma5. The rest of Sedum mates tested in the study were not fertilized before application. In the case of mineral and mineral-organic substrates, high P content is the result of chemical composition of components used in substrate preparation. 

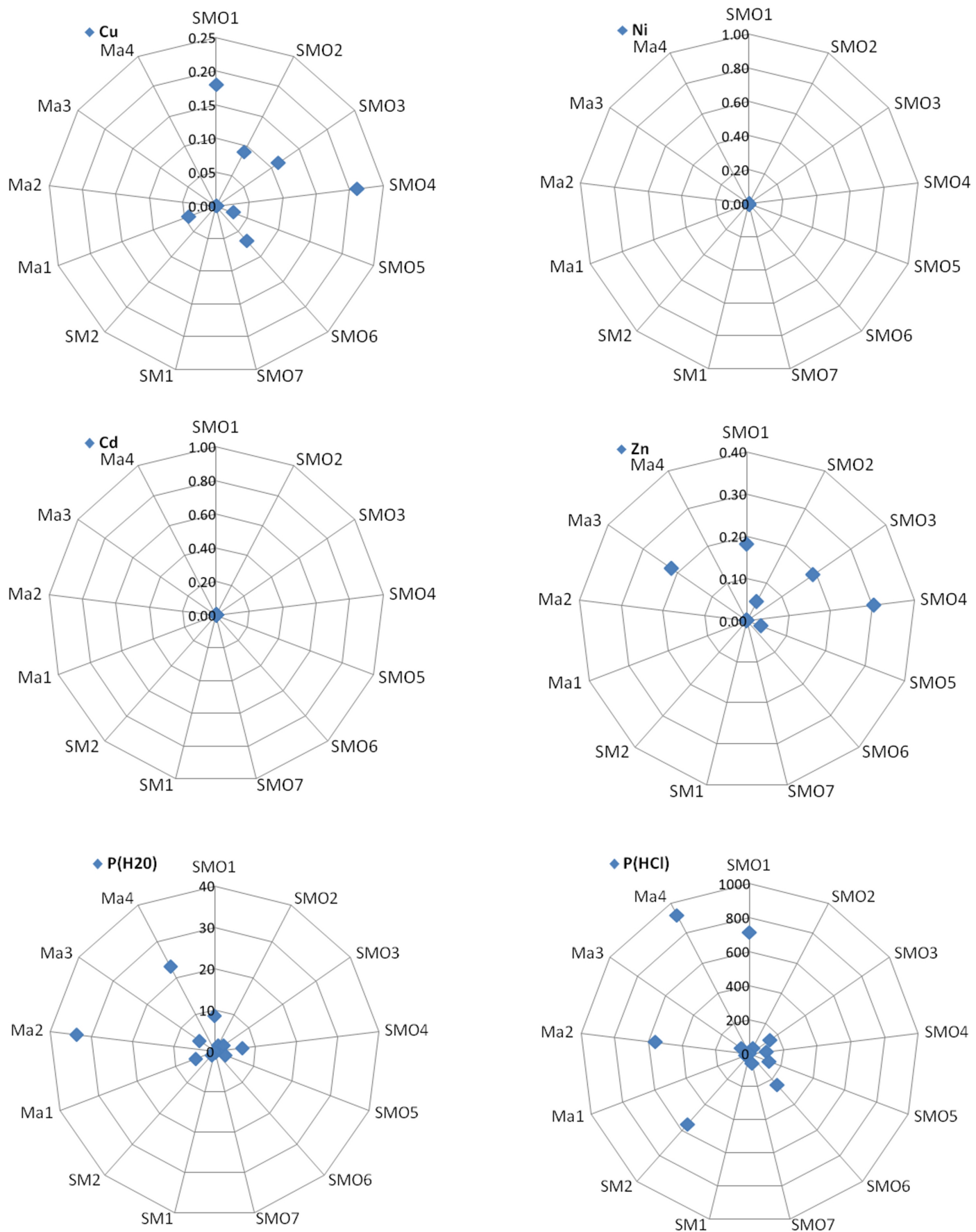

Figure 3. Metals and phosphorus content in tested green roof substrates $(\mathrm{mg} / \mathrm{kg})$.

Copper and zinc in high values of 2.04 and $6.34 \mathrm{mg} / \mathrm{kg}$, as well as phosphorus $(2002 \mathrm{mg} / \mathrm{kg}$ ) were also found in extracts from Ma5. As obtained values were extremely high, this sample was not taken into account in further comparisons and statistical analysis. Results were also not presented in Figures 3 and 4 to increase their readability. Contact with the manufacturer confirmed the fertilization of the mat Ma5 before delivery.

Six of twenty-nine tested mineral green roof substrate components were characterized by low phosphorus content (Figure 5). They were: Two of thirteen samples of sand (S11 and S12), two of two samples of limestone (L1 and L2), and two of five samples of LWA (LWA2 and LWA5). All samples of LWA-A and crushed red brick were characterized by high phosphorus content. LWA-A is a type of lightweight aggregate obtained by heat treatment (burning or sintering) of industrial wastes (e.g., ash). 
Crushed red brick usually comes from recycled brick debris. Both are an example of waste materials. Cascone [40] stated that crushed brick and construction waste are the most-used recycled material as an inorganic component in green roof substrates. Although the idea of waste recycling is noble, the use of such materials as a substrate component is not recommended due to potential contamination of receivers.

Most of the samples of sand (11/13) and all samples of gravel (3/3) were also polluted with phosphorus. For sands, phosphorus content varied from 9.52 to $266.93 \mathrm{mg} / \mathrm{kg}$ and for gravels from 8.25 to $95.13 \mathrm{mg} / \mathrm{kg}$. The highest value of phosphorus of $511.06 \mathrm{mg} / \mathrm{kg}$ was observed for crushed red brick.
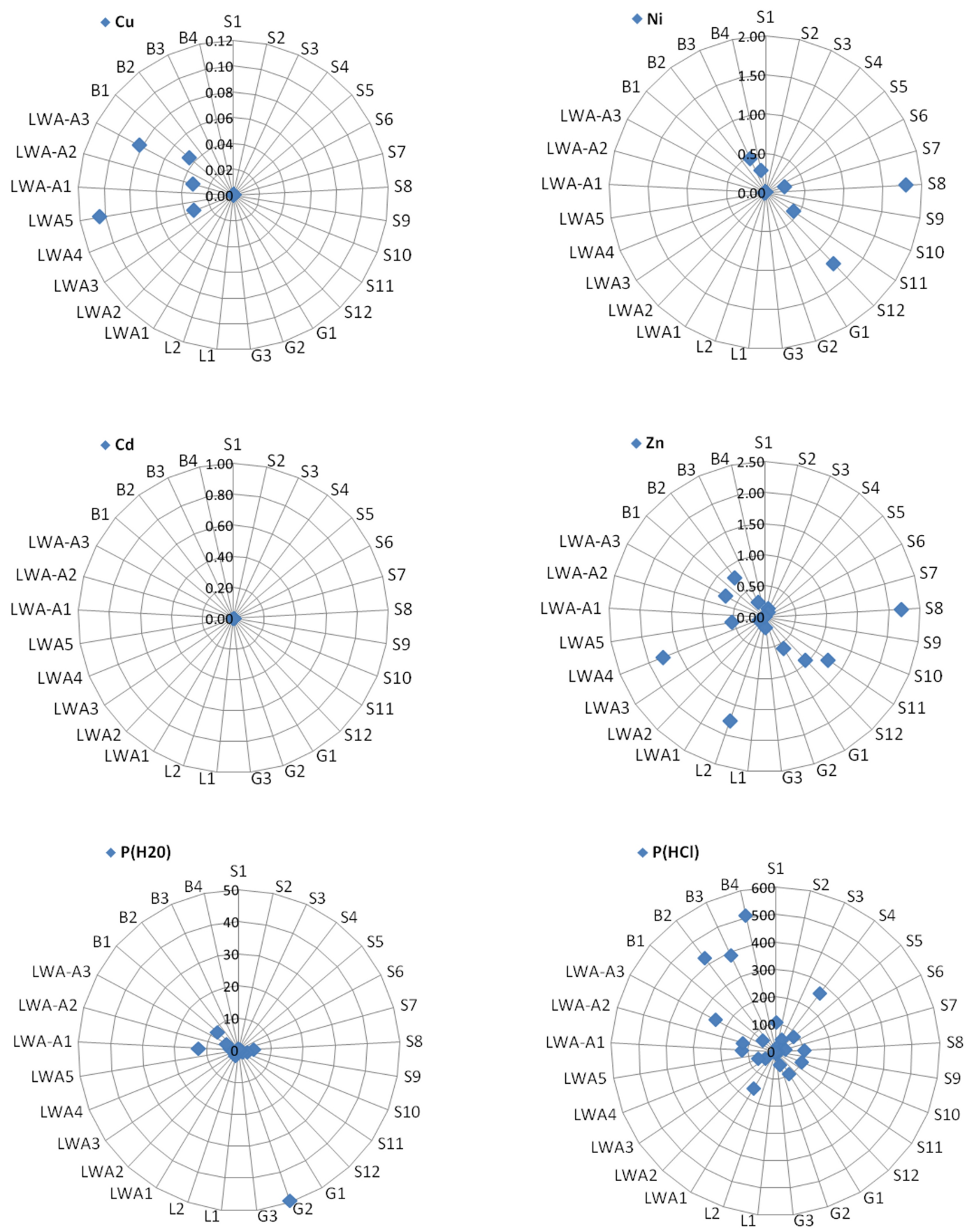

Figure 4. Metals and phosphorus content in tested green roof substrate components $(\mathrm{mg} / \mathrm{kg})$. 

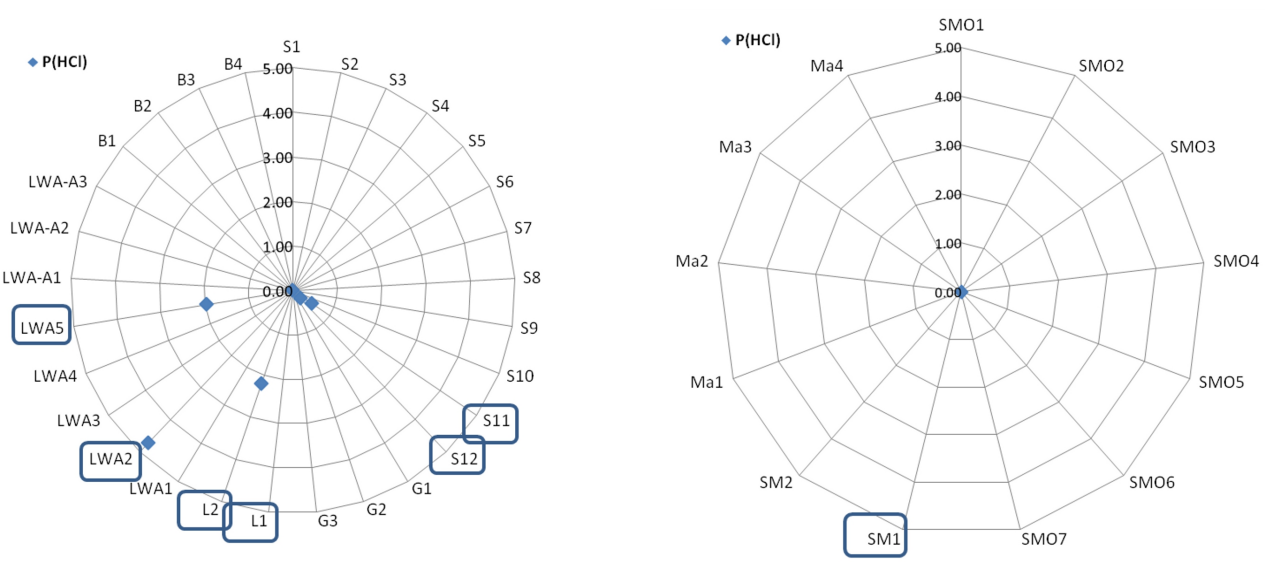

Figure 5. Substrate components and substrates below the limit [33] for P (mg/kg).

Correlation analysis between different detected contaminants of substrates and components was done, following the suggestion of Chen and $\mathrm{Li}$ [28], that a strong correlation between two paired pollutant loads makes it possible to consider one pollutant as a surrogate to estimate the other pollutant load, when measurements of the pollutant are missing or unreliable. In their study, metals such as iron, zinc, or aluminum may be considered as surrogates for predicting other pollutant loads [28]. In the case of mineral components, qualitative correlation results between two contaminants did not show strong correlation. In the case of substrates, phosphorus analyzed in water and chloric acid extracts was correlated with the value of correlation coefficient between 0.61 (mineral-organic substrates) and 0.84 (mineral substrates), which was not found in our previous study [20]. In mineral-organic substrates, a correlation between zinc and copper was also found (correlation coefficient 0.83 ), which was not detected in other substrates and materials. Based on results, it is not possible to consider any pollutant as a surrogate to estimate the other pollutant load. Any significant correlation was observed between contaminants and organic matter content in mineral-organic substrates.

Based on results of this study, we proposed the list of risky green roof substrates components (Table 3). The risk, which is connected with potential leaching of contaminants to urban receivers shows, that mostly phosphorus should be taken into consideration at the stage of selection of substrate components. Fourteen from 29 tested mineral materials are characterized as materials with very high risk of application, nine as materials with high risk of application. In the case of nickel, four of tested mineral materials are characterized as materials with high risk of application.

Table 3. The list of risky materials (green roof substrates components).

\begin{tabular}{|c|c|c|c|c|c|c|c|}
\hline \multirow{2}{*}{ Type of the Material } & \multirow{2}{*}{ Origin } & \multirow{2}{*}{ Symbol } & \multicolumn{5}{|c|}{ Rank } \\
\hline & & & $\mathrm{Cu}$ & $\mathbf{N i}$ & $\mathrm{Cd}$ & Zn & P (HCl) \\
\hline \multirow{12}{*}{ Sand } & \multirow{12}{*}{ Natural } & S1 & - & - & - & - & +++++ \\
\hline & & S2 & - & - & - & - & ++++ \\
\hline & & S3 & - & - & - & +++ & ++++ \\
\hline & & S4 & - & - & - & + & +++++ \\
\hline & & S5 & - & - & - & - & +++++ \\
\hline & & S6 & - & - & - & - & ++++ \\
\hline & & S7 & - & ++ & - & - & ++++ \\
\hline & & S8 & - & ++++ & - & ++ & +++++ \\
\hline & & S9 & - & - & - & - & ++++ \\
\hline & & S10 & - & - & - & - & +++++ \\
\hline & & S11 & - & ++++ & - & + & +++ \\
\hline & & S12 & - & ++++ & - & + & +++ \\
\hline
\end{tabular}


Table 3. Cont.

\begin{tabular}{|c|c|c|c|c|c|c|c|}
\hline \multirow{2}{*}{ Type of the Material } & \multirow{2}{*}{ Origin } & \multirow{2}{*}{ Symbol } & \multicolumn{5}{|c|}{ Rank } \\
\hline & & & $\mathrm{Cu}$ & $\mathbf{N i}$ & $\mathrm{Cd}$ & Zn & P (HCl) \\
\hline \multirow{3}{*}{ Gravel } & \multirow{10}{*}{ Man-made } & G1 & - & - & - & +++ & +++++ \\
\hline & & G2 & - & - & - & - & ++++ \\
\hline & & G3 & - & - & - & + & ++++ \\
\hline \multirow{2}{*}{ Limestone } & & L1 & - & - & - & - & - \\
\hline & & L2 & - & - & - & +++ & +++ \\
\hline \multirow{5}{*}{ Expanded clay } & & LWA1 & - & - & - & - & +++++ \\
\hline & & LWA2 & - & - & - & - & +++ \\
\hline & & LWA3 & - & - & - & + & ++++ \\
\hline & & LWA4 & + & + & - & +++ & ++++ \\
\hline & & LWA5 & +++ & - & - & ++ & +++ \\
\hline \multirow{3}{*}{$\begin{array}{l}\text { Expanded clay and } \\
\text { ash }\end{array}$} & & LWA-A1 & - & - & - & - & +++++ \\
\hline & & LWA-A2 & + & - & - & - & +++++ \\
\hline & & LWA-A3 & ++ & - & - & +++ & +++++ \\
\hline \multirow{4}{*}{ Crushed red brick } & & B1 & + & - & - & - & +++++ \\
\hline & & B2 & - & - & - & ++ & +++++ \\
\hline & & B3 & - & ++++ & - & + & +++++ \\
\hline & & B4 & - & + & - & - & +++++ \\
\hline
\end{tabular}

-: contaminant not detected, + : detected in one of three tested samples, $++:$ detected in two of three tested samples, +++ : detected in all tested samples but the mean value is below the limit (low risk of application), ++++ : mean value above the limit (high risk of application), +++++ : mean value one order of magnitude larger the limit (very high risk of application).

\section{Conclusions}

Only a few studies compare green roof runoff quality with substrate composition. Some of them show correlations between substrate composition and runoff quality in terms of loads, and some other studies show correlations between concentration of pollutants and the roof age and climatic factors. In this study, we tested readymade substrates and common used mineral substrate components for their release potential of phosphorus and selected metals. Substrates were not fertilized with the exception of Ma5, which was not considered in further analysis. It can therefore be assumed that this study shows potential pollution associated with the green roof structure.

From results of the present study, it is not possible to clearly state which materials should be used or avoided as substrate components, but it was possible to create a list of risky materials. From the materials of natural origin, sands and gravels can be polluted with phosphorus. In the group of man-made materials crushed red brick and LWA-A were strongly polluted with phosphorus. Those materials can create a risk of eutrophication of receivers of green roof runoff. Due to ecotoxicity of nickel, sands and crushed red brick can create an environmental risk. As a conclusion, it can be stated that more attention should be given to the quality of components of substrates used in the construction layers of green roofs.

Author Contributions: A.K., concept of the paper, plan of the experiment, collection of materials, extracts preparation, analysis, statistical analysis, concept of the results presentation, writing the manuscript; J.F., analysis of metals; A.B. (Anna Baryła), collection of materials, physical parameters, statistical analysis, and correction of the manuscript; A.B. (Agnieszka Bus), collection of materials and correction of the manuscript; J.M., correction of the manuscript. All authors have read and agreed to the published version of the manuscript.

Funding: This research received no external funding.

Acknowledgments: In this study we used research equipment belonging to Water Center SGGW.

Conflicts of Interest: The authors declare no conflict of interest. 


\section{References}

1. Enzi, V.; Cameron, B.; Dezsényi, P.; Gedge, D.; Mann, G.; Pitha, U. Nature-Based Solutions and Buildings-The Power of Surfaces to Help Cities Adapt to Climate Change and to Deliver Biodiversity. In Nature-Based Solutions to Climate Change Adaptation in Urban Areas; Springer: Cham, Switzerland, 2017; pp. 159-183.

2. Strategia adaptacji do zmian klimatu dla m.st. Warszawy do roku $2030 \mathrm{z}$ perspektywa do roku 2050. Miejski Plan Adaptacji. Available online: https://pliki.um.warszawa.pl/index.php/s/eHPc5HCkjpzQ2tK (accessed on 16 December 2019). (In Polish).

3. Berardi, U.; GhaffarianHoseini, A.H.; GhaffarianHoseini, A. State-of-the-art analysis of the environmental benefits of green roofs. Appl. Energy 2014, 115, 411-428. [CrossRef]

4. Peng, L.L.H.; Jim, C.Y. Economic evaluation of green-roof environmental benefits in the context of climate change: The case of Hong Kong. Urban For. Urban Green. 2015, 14, 554-561. [CrossRef]

5. Chen, C.F.; Kang, S.F. Effects of substrates and plant species on water quality of extensive green roofs. Appl. Ecol. Environ. Res. 2016, 14, 77-91. [CrossRef]

6. Catalano, C.; Laudicina, V.A.; Badalucco, L.; Guarino, R. Some European green roof norms and guidelines through the lens of biodiversity: Do ecoregions and plant traits also matter? Ecol. Eng. 2018, 115, 15-26. [CrossRef]

7. Song, K.; Xenopoulos, M.A.; Marsalek, J.; Frost, P.C. The fingerprints of urban nutrients: Dynamics of phosphorus speciation in water flowing through developed landscapes. Biogeochemistry 2015, 125, 1-10. [CrossRef]

8. Paul, M.J.; Meyer, J.L. Streams in the urban landscape. Annu. Rev. Ecol. Syst. 2001, 32, 333-365. [CrossRef]

9. Barałkiewicz, D.; Chudzińska, M.; Szpakowska, B.; Świerk, D.; Gołdyn, R.; Dondajewska, R. Storm water contamination and its effect on the quality of urban surface waters. Environ. Monit. Assess. 2014, 186, 6789-6803. [CrossRef] [PubMed]

10. Pluta, K.; Mrowiec, M. Analiza oddziaływania systemów kanalizacyjnych na odbiornik. Inżynieria Ekol. 2015, 45, 183-194. (In Polish) [CrossRef]

11. IMGW. Ocena możliwości i warunków osiagnnięcia celów redukcyjnych HELCOM dla azotu i fosforu. II Bałtycki Okrąły Stół, 13 maja 2014 r. Available online: http://awsassets.wwfpl.panda.org/downloads/ prezentacja_imgw_waldemar_jarosinski_ocena_mozliwoci_i_warunkow_osiagnicia_celow_r_1.pdf (accessed on 13 May 2014). (In Polish)

12. Toland, D.C.; Haggard, B.E.; Boyer, M.E. Evaluation of nutrient concentrations in runoff water from green roofs, conventional roofs, and urban streams. Trans. ASABE 2012, 55, 99-106. [CrossRef]

13. Bliss, D.J.; Neufeld, R.D.; Ries, R.J. Storm Water Runoff Mitigation Using a Green Roof. Environ. Eng. Sci. 2009, 26, 407-418. [CrossRef]

14. Barr, C.M.; Gallagher, P.M.; Bridget, P.E.; Wadzuk, B.M.; Welker, A.L. Water Quality Impacts of Green Roofs Compared with Other Vegetated Sites. J. Sustain. Water Built Environ. 2017, 3, 04017007. [CrossRef]

15. Ferrans, P.; Rey, C.V.; Pérez, G.; Rodríguez, J.P.; Díaz-Granados, M. Effect of Green Roof Configuration and Hydrological Variables on Runoff Water Quantity and Quality. Water 2018, 10, 960. [CrossRef]

16. Moran, A.; Hunt, B.; Smith, J. Hydrologic and water quality performance from greenroofs in Goldsboro and Raleigh, North Carolina. In Proceedings of the Third Annual Greening Rooftops for Sustainable Communities Conference, Awards and Trade Show, Washington, DC, USA, 4-6 May 2005.

17. Czemiel Berndtsson, J.; Emilsson, T.; Bengtsson, L. The influence of extensive vegetated roofs on runoff water quality. Sci. Total Environ. 2006, 355, 48-63. [CrossRef] [PubMed]

18. Hathaway, A.M.; Hunt, W.F.; Jennings, G.D. A field study of green roof hydrologic and water quality performance. Trans. Am. Soc. Agric. Biol. Eng. 2008, 51, 37-44. [CrossRef]

19. Gregoire, B.G.; Clausen, J.C. Effect of a modular extensive green roof on stormwater runoff and water quality. Ecol. Eng. 2011, 37, 963-969. [CrossRef]

20. Karczmarczyk, A.; Bus, A.; Baryła, A. Phosphate Leaching from Green Roof Substrates-Can Green Roofs Pollute Urban Water Bodies? Water 2018, 10, 199. [CrossRef]

21. Akther, M.; He, J.; Chu, A.; Valeo, C.; Khan, U.T.; van Duin, B. Response of green roof performance to multiple hydrologic and design variables: A laboratory investigation. Water Sci. Technol. 2018, 77, $2834-2840$. [CrossRef] 
22. Buffam, I.; Mitchell, M.E. Nutrient Cycling in Green Roof Ecosystems. In Green Roof Ecosystems; Ecological Studies 223; Springer International Publishing: Cham, Switzerland, 2015; pp. 107-137.

23. Buffam, I.; Mitchell, M.E.; Durtsche, R.D. Environmental drivers of seasonal variation in green roof runoff water quality. Ecol. Eng. 2016, 91, 506-514. [CrossRef]

24. Wang, J.; Zhang, P.; Yang, L.; Huang, T. Adsorption characteristics of construction waste for heavy metals from urban stormwater runoff. Chin. J. Chem. Eng. 2015, 23, 1542-1550. [CrossRef]

25. Fronczyk, J.; Radziemska, M.; Dynowski, P.; Mazur, Z.; Bazydło, M. Quality of water in the road drainage systems in the Warsaw agglomeration, Poland. Water 2016, 8, 429. [CrossRef]

26. Berndtsson, C.J.; Bengtsson, L.; Jinno, K. Runoff water quality from intensive and extensive vegetated roofs. Ecol. Eng. 2009, 30, 271-277. [CrossRef]

27. Fassman, E.; Simcock, R.; Voyde, E.; Hong, Y.S. 4 living roofs in 3 locations: Does configuration affect runoff quality or quantity? J. Hydrol. 2013, 490, 11-20. [CrossRef]

28. Chen, J.; Li, J. Characterization of Green Roof Stormwater Runoff Quality. J. Water Manag. Modeling 2011, R241-18. [CrossRef]

29. Mitchell, M.E.; Matter, S.F.; Durtsche, R.D.; Buffam, I. Elevated phosphorus: Dynamics during four years of green roof development. Urban Ecosyst. 2017, 20, 1121-1133. [CrossRef]

30. Beecham, S.; Razzaghmanesh, M. Water quality and quantity investigation of green roofs in a dry climate. Water Res. 2015, 70, 370-384. [CrossRef] [PubMed]

31. International Organization for Standardization (ISO). PN EN 1097-3:2000 Equivalent to EN 1097-3:1998 Tests for Mechanical and Physical Properties of Aggregates. Determination of Loose Bulk Density and Voids; International Organization for Standardization (ISO): Geneva, Switzerland, 2000.

32. Karczmarczyk, A.; Baryła, A.; Kożuchowski, P. Design and Development of Low P-Emission Substrate for the Protection of Urban Water Bodies Collecting Green Roof Runoff. Sustainability 2017, 9, 1795. [CrossRef]

33. Richtlinien für Planung, Bau und Instandhaltung von privaten Schwimm- und Badeteichen; Forschungsgesellschaft Landschaftsentwicklung Landschaftsbau e.V.: Bonn, Germany, 2017.

34. International Organization for Standardization (ISO). PN EN 933-1:2012 Equivalent to EN 933-1:2012 Tests for Geometrical Properties of Aggregates. Determination of Particle Size Distribution-Sieving Method; International Organization for Standardization (ISO): Geneva, Switzerland, 2012.

35. International Organization for Standardization (ISO). PN-EN 1936:2010 Equivalent to EN 1936:2006 Natural Stone Test Methods. Determination of Real Density and Apparent Density, and of Total and Open Porosity; International Organization for Standardization (ISO): Geneva, Switzerland, 2000.

36. Official Journal of the European Communities. COUNCIL DECISION of 19 December 2002 Establishing Criteria and Procedures for the Acceptance of Waste at Landfills Pursuant to Article 16 and Annex II to Directive 1999/31/EC (2003/33/EC); Official Journal of the European Communities L 011, 0027-0049; European Commission: Luxembourg, 2013.

37. Cloran, C.E.; Burton, G.A.; Hammerschmidt, C.R.; Taulbee, W.K.; Custer, K.W.; Bowman, K.L. Effects of suspended solids and dissolved organic carbon on nickel toxicity. Environ. Toxicol. Chem. 2010, 29, 1781-1787. [CrossRef] [PubMed]

38. Costello, D.M.; Burton, G.A.; Hammerschmidt, C.R.; Taulbee, W.K. Evaluating the performance of diffusive gradients in thin films for predicting Ni sediment toxicity. Environ. Sci. Technol. 2012, 46, 10239-10246. [CrossRef] [PubMed]

39. Custer, K.W.; Hammerschmidt, C.R.; Burton, G.A., Jr. Nickel toxicity to benthic organisms: The role of dissolved organic carbon, suspended solids, and route of exposure. Environ. Pollut. 2016, 208, 309-317. [CrossRef]

40. Cascone, S. Green Roof Design: State of the Art on Technology and Materials. Sustainability 2019, 11, 3020. [CrossRef]

(C) 2020 by the authors. Licensee MDPI, Basel, Switzerland. This article is an open access article distributed under the terms and conditions of the Creative Commons Attribution (CC BY) license (http://creativecommons.org/licenses/by/4.0/). 